\title{
Managing PBL Difficulties in an Industrial Engineering and Management Program
}

\author{
Anabela Alves (iD, Rui Sousa (iD), Francisco Moreira (D), M. Alice Carvalho (D), Elisabete Cardoso (D), \\ Pedro Pimenta (D), M. Teresa Malheiro (D), Irene Brito (D), Sandra Fernandes (D), Diana Mesquita (i)
} University of Minho (Portugal)

anabela@,dps.uminho.pt,rms@,dps.uminho.pt,fmoreira@,dps.uminho.pt,.mac@,quimica.uminho.pt, elisabete@dsi.uminho.pt, pedroccpimenta@gmail.com,.mtm@math.uminho.pt, ireneb@math.uminho.pt, sandra@dps.uminho.pt, diana@,dps.uminho.pt

Received: December 2015

Accepted: March 2016

\section{Abstract:}

Purpose: Project-Based Learning (PBL) is considered to be an active learning methodology which can be used to develop both technical and transversal competences in engineering programs. This methodology demands a great deal of work effort from the students and also from the teachers and it requires a meticulous plan and a well-managed project as well. These activities go far beyond the normal activities in traditional lectures, enabling to outpace the difficulties that spur along the way that may be both complex and demotivating. This methodology has been implemented in the Integrated Master Degree on Industrial Engineering and Management (IEM), at one public university in Portugal, since the 2004/2005 academic year. The aim of this paper is to identify and discuss the main difficulties of the implementation of PBL, mainly from the teachers' perspectives. Additionally, some effective strategies will be recommended to overcome such difficulties.

Design/methodology/approach: The perceptions of the teachers were collected through a survey based on six main themes. The participants in the study include eight teachers from the five courses of the first semester of the first year of the IEM program involved in the 2012/2013 and 2013/2014 editions. 
Findings: Integration of courses in the project; student assessment; growing number of students in each team and the need of physical spaces for them; and compartmentalized knowledge has emerged as the main difficulties. To overcome these difficulties some key strategies were recommended.

Originality/value: A new perspective based on course teachers' views and experiences will deepen the understanding of the problems and provide inputs for the development of strategies that may improve the effectiveness of PBL and introduce changes for its successful implementation. These strategies are intended to be transferable to other contexts, as most of the problems and constraints are common to other active learning approaches.

Keywords: project-based learning, active learning, engineering education, industrial engineering and management curriculum

\section{Introduction}

A general concern in all levels of education is that of a better preparation of students. One key precondition to its effective achievement is the deployment of suitable learning methodologies, which might exploit ones natural will and motivation to learn. Other pre-sets may include more flexible structures to allow for quicker curriculum redesign, better preparation of teachers, etc. Many organizations across the globe are actively involved in promoting initiatives and taking action in order to improve education. These include universities, professional associations, government agencies and even enterprises.

At the Higher Education level, the European Commission has recently launched a report, developed by the High Level Group on the Modernization of Higher Education, concerned with improving the quality in teaching and learning in Higher Education Institutions (European Commission, 2013). Sixteen recommendations were reported, among which, one specifically targeted the introduction and promotion of cross-, trans- and interdisciplinary approaches to teaching, learning and assessment, with the aim to aid students to actively pursue and develop their breadth of understanding and technical skills, develop transversal skills and promote a mind-set for entrepreneurship and innovation. This recommendation is particularly meaningful in the context of Engineering Education (EE), given that engineering practice requires a permanent awareness of technical developments and innovation, derived from global competition and highly dynamic marketplace. 
As pointed out by King (2012) a rapid change in Engineering Education is required, grounded on a number of different needs, namely: 1) better understanding of the human condition, cultures and society; 2) ability to work effectively with public policy, business and government; 3) understanding of the innovation process and of its prime enabling factors; 4) ability to work synergistically with peers from other discipline areas, including non-science/engineering fields, such as management, law, economics, public policy, political science, and sociology; 5) ability to communicate effectively and to express technical issues in simple, understandable terms; and 6) general liberal education, integrated with engineering education.

One possible approach to the underlined thread of reasoning is that of embracing active learning methodologies in Engineering Education, aiming to tackle the endeavor of promoting student-centered instruction, peer-to-peer networks, and emphasis on collaboration and a balance on individual and teamwork (Zhang, Zimmerman, Milhelicic \& Vanasupa, 2008). In active learning, the role of the teacher may well migrate from an intensive and one way flow instruction (from the teacher to the class, i.e. teacher-centered instruction), to a coach and mentor fashion, where the teacher supports the learning process of individual students or teams (Prince, 2004). One methodology that is recognized to promote active learning is that of Project-Based Learning (PBL).

PBL has roots on the seminal works of Dewey (1916) and Kilpatrick $(1918,1921)$, which defended that the preparation of students for their active participation on the real life should be made in a meaningful and purposeful environment. Several engineering programs all over the world have been implementing PBL. Some examples: Ollin College (United States of America), Aalborg University (Denmark) and University of Twente (The Netherlands). There is no single model for PBL. It depends on the particularities of the contexts and the people involved in the process (e.g. teachers, students, deans, etc.). However, there are some common guidelines in those models, which define and distinguish PBL from other types of projects (Helle, Tynjälä \& Olkinuora, 2006), namely the interdisciplinary curriculum approach, teamwork environment, link between theory and practice. Also the project should be based on an open-ended problem that provides more than one solution (Bédard, Lison, Dalle, Côté \& Boutin, 2012; Edström \& Kolmos, 2014; Graaff \& Kolmos, 2003; Jollands, Jolly \& Molyneaux, 2012).

PBL was the active learning methodology chosen for a paradigmatic shift of the instruction of the Industrial Engineering and Management (IEM) Master Degree program at a public university in Portugal. On the earlier 2004/2005 academic year, after a training session on Project-Led Education (PLE) (Powell $\&$ Weenk, 2003), and encouraged by the former rectory, a team of teachers promoted a first experience in PBL in the first year of the IEM program. After that, this methodology was successfully implemented on a continuous basis, for more than a decade. In addition, an action-research improvement spiral took place since the beginning, given that PBL does not only involve students in their own learning, as any other 
active methodology (Graaff \& Kolmos, 2007; Lima, Carvalho, Flores \& van Hattum-Janssen, 2007; Prince, 2004), it also involves teachers on improving their own practices (Lima, Carvalho, Sousa \& Alves, 2009; Alves, Sousa, Fernandes, Cardoso, Carvalho, Figueiredo, et al., 2015a). This process is pulled by students and teachers' demands and feedback, and by a more clear awareness of needs for improvement of the PBL methodology in this IEM program.

The foregoing sets the stage for a clear endorsement of the difficulties that one such endeavor represents, i.e. the implementation of a PBL methodology within the context of Engineering Education. The study presented here is grounded on the perceptions and reflections of the teachers involved in the PBL program. The perceptions were collected through a 12 open-ended questions survey grouped in six themes, which were gathered at the end of the 2013/2014 edition. The participants consist of eight teachers, which pertain to five distinct project supporting courses (PSC), of the first year of the IEM program (IEM11_PBL) from two editions (or cohorts): 2012/2013 and 2013/2014. The perceptions, as well as PBL process improvement suggestions, were analyzed to infer about the difficulties felt by the teachers. Additionally, attending to the many years of respondent's PBL experience, some effective strategies are outlined with an intention to help others that want to initiate or have already initiate a similar learning project.

This paper is organized in six sections. Following this introduction, the study context is presented in section two. The research methodology is described in section three. The teachers' perspectives on the PBL difficulties are exposed in section four, followed by discussion of results and presentation of some effective strategies recommended to overcome such difficulties, in section five. Sixth section presents the foremost remarks of the study.

\section{Study Context}

The work reported in this paper is developed in the context of the first year, first semester of the Integrated Master Degree on Industrial Engineering and Management (IEM) from a public Portuguese university with approximately 18000 students. The designation "Integrated Master" appears after the "Bologna process" (European Ministers of Education, 1999), and identifies an education degree with two cycles: six semesters (graduation) plus four semesters (master degree), comprising a total of 300 European Credits Transfer System (ECTS). One ECTS represents 25 to 30 hours/semester of student work (20 weeks).

The first semester of the first year of IEM usually includes six courses (Table 1), each with five ECTS, and this university considers that one ECTS corresponds to 28 hours/semester of student work. Thus, each course implies $140 \mathrm{~h} /$ semester of student work and the direct contact hours (contact with the teacher) should not exceed $50 \%$ of that value. 


\begin{tabular}{|c|c|c|c|}
\hline Acronym & Curricular Unit (Course) & Scientific area & ECTS \\
\hline LAlg. & Linear Algebra & Basic Sciences & 5 \\
\hline CC & Calculus C & Basic Sciences & 5 \\
\hline GC & General Chemistry & Basic Sciences & 5 \\
\hline AP & Algorithms and Programming & Basic Sciences & 5 \\
\hline TIEM & Topics of Industrial Engineering and Management & Specialty Sciences & 5 \\
\hline IPIEM1 & Integrated Project in Industrial Engineering and Management I & Engineering Sciences & 5 \\
\hline
\end{tabular}

Table 1 . Courses of the $1^{\text {st }}$ year, $1^{\text {st }}$ semester of the IEM Integrated Master Degree

As can be observed in Table 1, four of the courses are classified in the area of Basic Sciences, one in the area of Engineering Sciences, and one in the area of Specialty Sciences. These courses are lectured by teachers that belong to different schools and departments of this university, as shown in Figure 1.
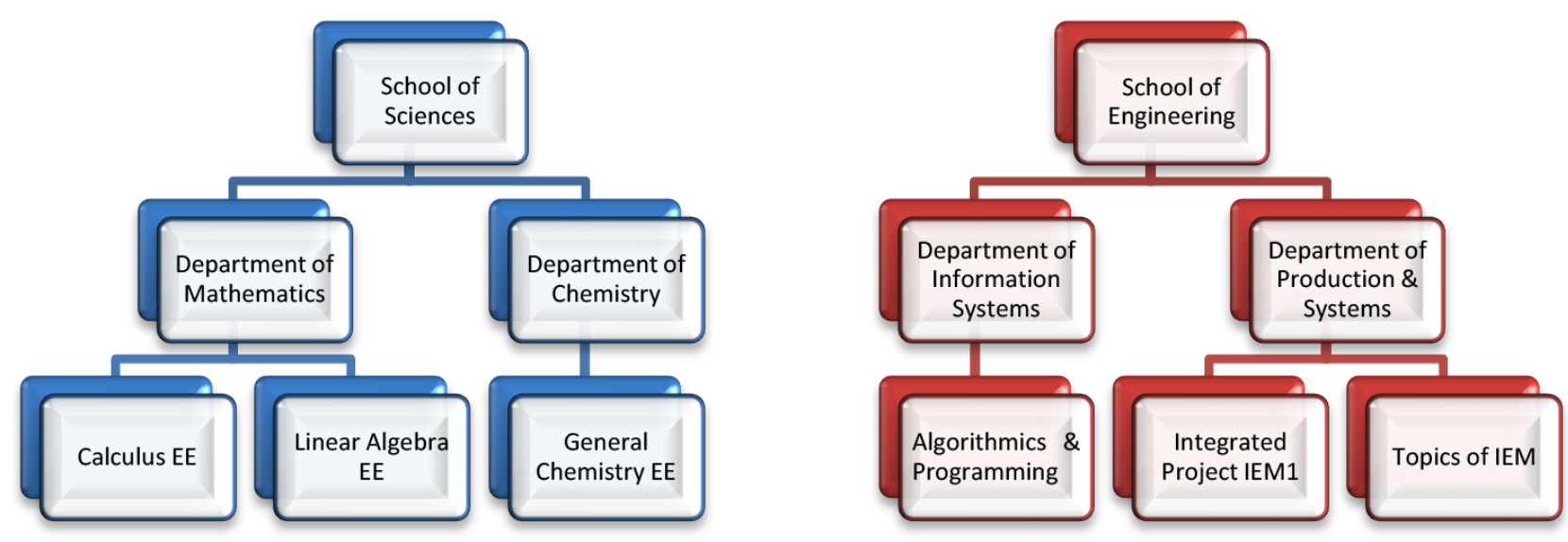

Figure 1. Distribution of IEM courses of $1^{\text {st }}$ year, $1^{\text {st }}$ semester by schools and departments

\subsection{Integrated Project IEM1 and Project Supporting Courses}

It is important to clarify that the IPIEM1 course was included in the IEM curriculum after eight editions of PBL implementation. This decision was taken mainly due to the students' feedback, which was collected through questionnaires every year. So, the IPIEM1 course emerged only in the 2012/2013 edition (or cohort) and before this curricular change, the project grade was embedded in each course grade (Alves, Moreira, Lima, Sousa, Carvalho, Mesquita et al., 2015b).

In the PBL methodology, team-based student activity is focused in solving a large-scale open-ended project. To develop this project, the student teams must learn and apply concepts taught in the classes of the different courses (Table 1). Additionally, they use tools and resources (e.g. Lego Mindstorms kits), 
laboratories and project rooms to conduct the activities necessary to achieve the project conclusion (Figure 2). Normally, six student teams are formed, each one with a tutor and a project room space provided by the department where teams work during the project development and, sometimes, teachers met with the team for project support.

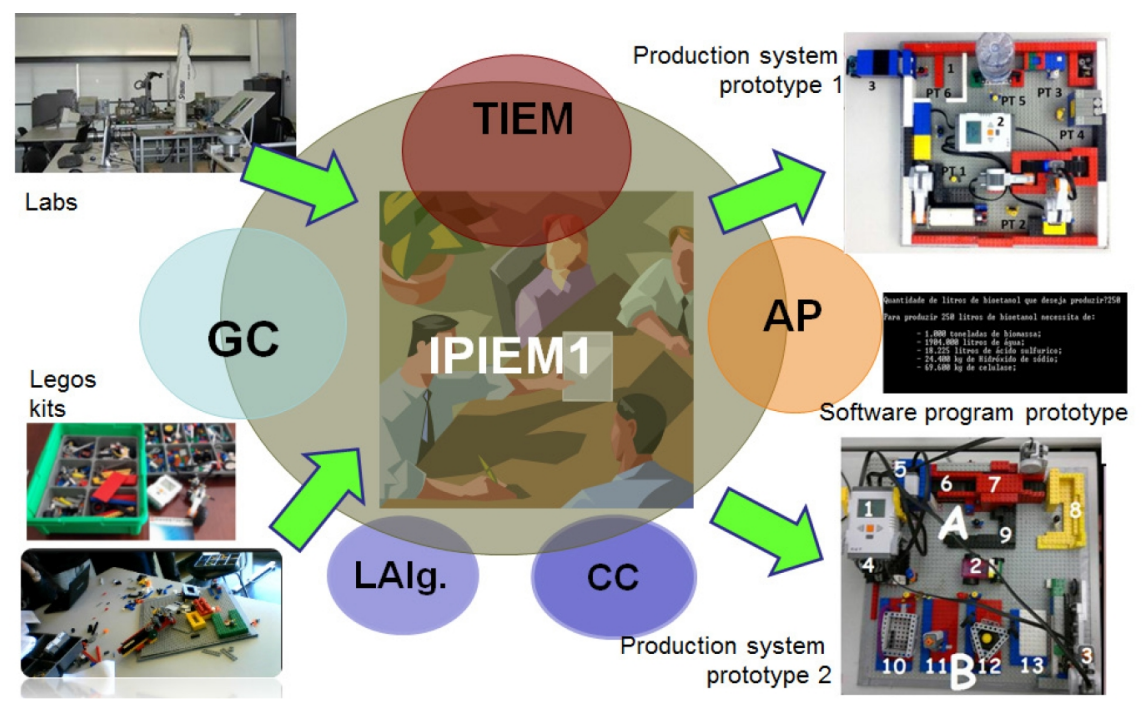

Figure 2. Some resources used by student teams to produce project outputs

Each course defines the contents that students must apply in the project. For some courses those contents will match almost all the syllabus (e.g. TIEM) while for others they will represent only a part (e.g. CC). Besides the lectures, teachers must provide support to the student teams (additional time considered in the teacher workload). TIEM is the PSC with more workload due to its central role in the project development (core of the IEM program). To schedule these support periods for each course along the semester, a detailed plan was developed considering that each course has, approximately, 15 hours/semester to support the six student teams (TIEM has 45 hours because of its central role, as previously referred) (see Figure 3). 


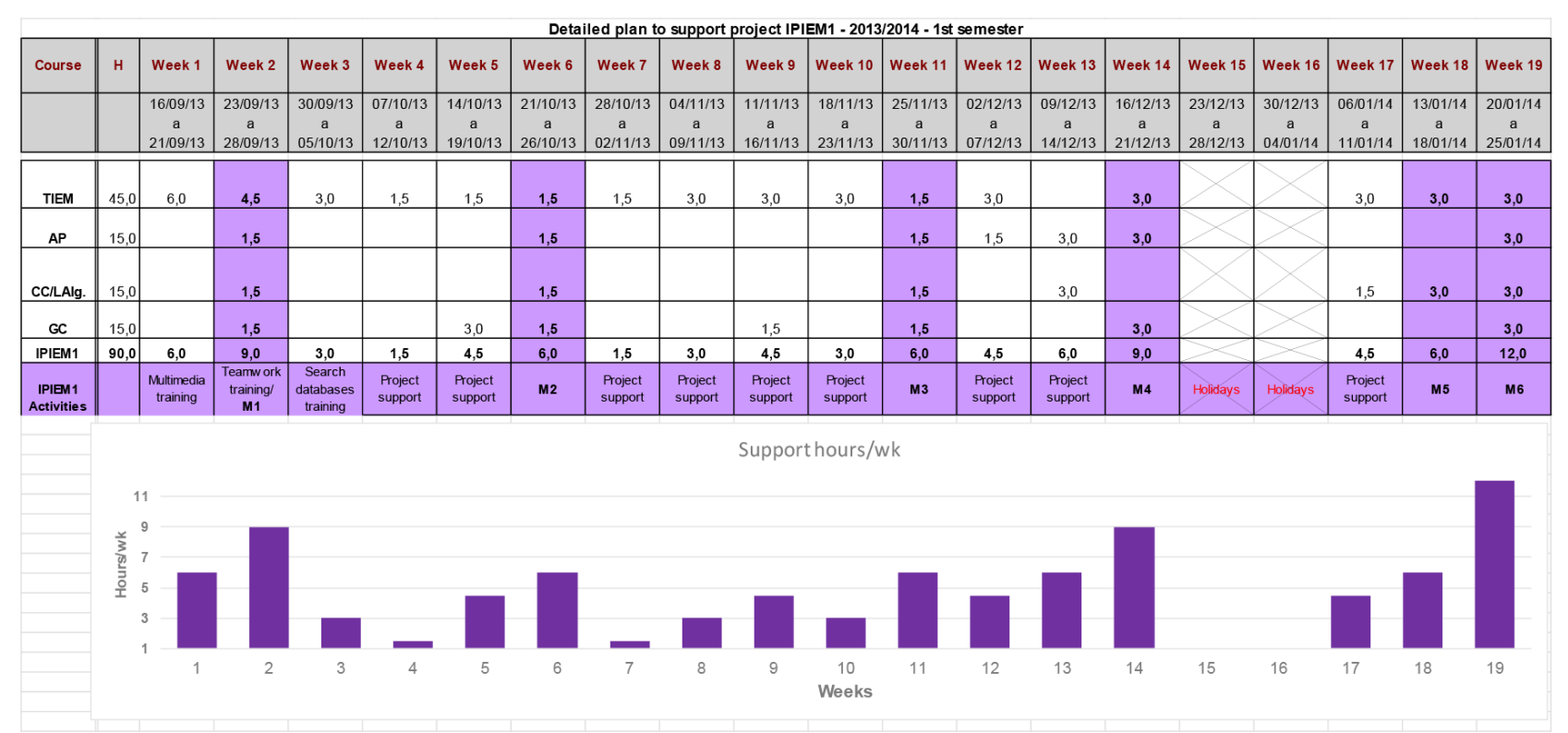

Figure 3. Detailed plan to support IPIEM1 in 2013/2014

In this plan it is possible to see that the students teams had IPIEM1 activities all weeks (in average three hours for each team per week), represented in the graph, including project support from courses or others activities such as training sessions (e.g. teamwork) or project milestones (M1, M2, M3, M4, M5 and M6) defined in the project plan (section 4.5). Also, each course teacher defined at the beginning of the semester what is the best period to support the students. For example, Chemistry is needed from the project beginning to help students deciding about the project to develop, so this support is given first. Algorithms and Programming, Calculus C and Linear Algebra are needed in a final phase of the project.

\subsection{Coordination Team}

The coordination team of the 2012/2013 and 2013/2014 editions of PBL was constituted by the courses teachers, tutors, and educational researchers. The Table 2 shows the teachers involved in the first semester of first year of IEM, the school and department they belong to, years of participation and role in PBL editions. 


\begin{tabular}{|c|c|c|c|c|}
\hline Course & Teacher & School/Department & $\begin{array}{l}\text { Participation } \\
\text { in PBL Editions }\end{array}$ & Role(s) in PBL \\
\hline \multirow{3}{*}{$\begin{array}{l}\text { Topics of Industrial } \\
\text { Engineering and } \\
\text { Management (TIEM) }\end{array}$} & Teacher1_TIEM & $\begin{array}{l}\text { School of Engineering, Depart. } \\
\text { Production Systems }\end{array}$ & 9 years & $\begin{array}{c}\text { Teacher } \\
\text { Tutor } \\
\text { PBL Coordinator }\end{array}$ \\
\hline & Teacher2_TIEM & $\begin{array}{l}\text { School of Engineering, Depart. } \\
\text { Production Systems }\end{array}$ & 9 years & $\begin{array}{c}\text { Teacher } \\
\text { Tutor } \\
\text { PBL Coordinator }\end{array}$ \\
\hline & Teacher3_TIEM & $\begin{array}{l}\text { School of Engineering, Depart. } \\
\text { Production Systems }\end{array}$ & 9 years & $\begin{array}{c}\text { Teacher } \\
\text { Tutor } \\
\text { PBL Coordinator }\end{array}$ \\
\hline General Chemistry (GC) & Teacher4_GC & $\begin{array}{l}\text { School of Sciences, } \\
\text { Depart. of Chemistry }\end{array}$ & 3 years & Teacher \\
\hline \multirow{2}{*}{$\begin{array}{l}\text { Algorithms and } \\
\text { Programming (AP) }\end{array}$} & Teacher5_AP & $\begin{array}{l}\text { School of Engineering, Depart. } \\
\text { Information Systems }\end{array}$ & 9 years & Teacher \\
\hline & Teacher6_AP & $\begin{array}{l}\text { School of Engineering, Depart. } \\
\text { Information Systems }\end{array}$ & 3 years & Teacher \\
\hline Calculus C (CC) & Teacher7_CC & $\begin{array}{l}\text { School of Sciences, Depart. of } \\
\text { Mathematics and Applications }\end{array}$ & 3 years & Teacher \\
\hline Linear Algebra (LAlg.) & Teacher8_LAlg. & $\begin{array}{l}\text { School of Sciences, Depart. of } \\
\text { Mathematics and Applications }\end{array}$ & 1 year & Teacher \\
\hline
\end{tabular}

Table 2. Coordination team of the 2012/2013 and 2013/2014 editions of PBL in IEM

Normally, the project team coordinator is a teacher of TIEM and has one hour per week to coordinate the PBL process, to organize the student activities, to solve problems that students may have, to reserve rooms for the presentations, to schedule meetings with the coordination team, among other tasks.

\subsection{Project Themes}

The project themes are always chosen carefully by the coordination team attending to the importance of engaging students in their own learning and in solving real-life problems. The project must be challenging and work as a conscience trigger to motivate and educate the future engineers. So, attending to these criteria, the themes have been related with environmental problems (Moreira, Mesquita \& van Hattum-Janssen, 2011) and, for the 2012/2013 and 2013/2014 editions, they were:

- Specification of a disassembly line for recycling of waste electrical and electronic equipment (WEEE)

- Design of a more sustainable packaging and specification of the production system

The coordination team intention is to develop in the young students the awareness for the sustainability issues. 


\subsection{Project Phases, Activities and Milestones}

The IPIEM1 project is developed according to the following phases: preparation, setup, start-up, execution and conclusion (Alves, Moreira, Sousa \& Lima, 2009) (Figure 4a). The phases with higher workloads for teachers are the setup and conclusion (Mesquita, Alves, Fernandes, Moreira \& Lima, 2009). The setup implies a lot of decisions related with the project development and monitoring, such as definition of milestones and assessment model. In every edition these important elements are discussed and throughout the years the IPIEM1 has known different numbers and types of milestones and changes to the assessment model (Moreira, Sousa, Leão, Alves \& Lima, 2009; Fernandes, Lima \& Flores, 2009; Alves et al., 2015b). The milestones of the 2013/2014 edition are presented in Figure 4b. Milestones 1 (M1) and 3 (M3) are not assessed because the first one corresponds to the first presentation (it is like a first experience) and milestone 3 (M3) corresponds to the extended tutorial (each team of students receives feedback from all the teachers).

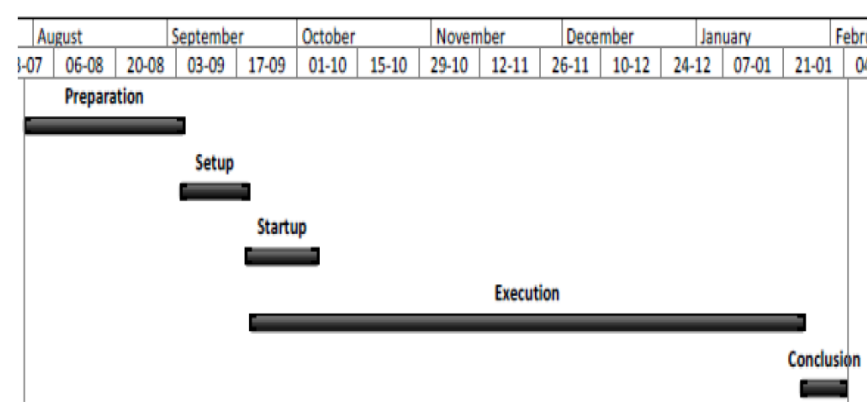

a)

\begin{tabular}{ccl}
\hline Milestone & Date & \multicolumn{1}{c|}{ Requisite } \\
\hline 1 & Week 2 & Pilot Project presentation \\
\hline 2 & Week 7 & Project progress presentation \\
\hline 3 & Week 10 & Extended tutorial \\
\hline 4 & Week 13 & Preliminary report (maximum of 50 pages) \\
\hline 5 & Week 16 & Final report (maximum of 60 pages) + Prototypes \\
\hline 6 & Week 17 & Final individual written test; \\
\hline
\end{tabular}

b)

Figure 4. a) Project phases and b) milestones of 2013/2014 edition

Normally, the academic year at this university starts in mid-September and after the first three days of events in the university, students are introduced to the PBL methodology and to the project they have to develop in the next five months in the IPIEM1 course. This is introduced by the project team coordinator in a public session where the students come to know the teachers of the semester, receive the plan for the first two weeks and the project guide. The project guide is a document created by the coordination team with all information about PBL methodology, the objectives and a brief description of the project, the composition of the coordination team, the learning outcomes of each course, the assessment model of the project and of each course and the available resources (e.g. project rooms, lockers and e-learning platform).

In this session, students must form the teams according to the criteria defined by the coordination team. Due to space constraints, the number of teams is limited to six and each team may have at most nine 
elements. Also, in this session, it is assigned a tutor to each team. This tutor will have the function of monitoring the team work and progress, and helping the team to overcome conflicts or difficulties and discussing the peer assessment process. Finally, each team is led to a project room, previously allocated by the project team coordinator.

After a week, the teams must present the pilot project (Figure $4 \mathrm{~b}$ - milestone 1 ) to the coordination team and colleagues. This is a stressful week due to the number of project tasks they have to do, along with all the activities inherent to the freshmen status (new people, new house and new environment ...). Even so, their opinion about this is positive and after many years they still remember this experience as something good (Alves, Moreira, Lima, Sousa, Carvalho, Mesquita et al., 2012a). After this week, the students are prepared for the rest of the semester's workload. The semester finishes with a workshop organized by the project team coordinator with educational researchers' collaboration to collect feedback from the students. A detailed description of the phases, milestones and workshop can be found in Alves et al. (2015a).

\subsection{Project Assessment Model}

The project assessment model includes a project individual grade and a written test individual grade, as shown in Figure 5. The individual project grade is obtained from a project team grade multiplied by an individual correction factor resulted from a peer assessment. The project team grade is obtained from deliverables monitored in the milestones: preliminary and final reports, presentations (two) and prototypes. Each one has a different weight (Figure 5) decided in the project setup phase by the coordination team.

One quarter of the percentage of $25 \%$ from the preliminary report assessment is provided by the students 'teams. Using a spreadsheet prepared by the teachers with the contents to include in the report, students must assess, at least, one report from the colleagues. The main idea with this is to actively engage students in the process of assessing other students and to see where they failed and what they did well in their own report. By doing this the students also learn with the experience. This spreadsheet is also used by teachers to assess the preliminary report. 


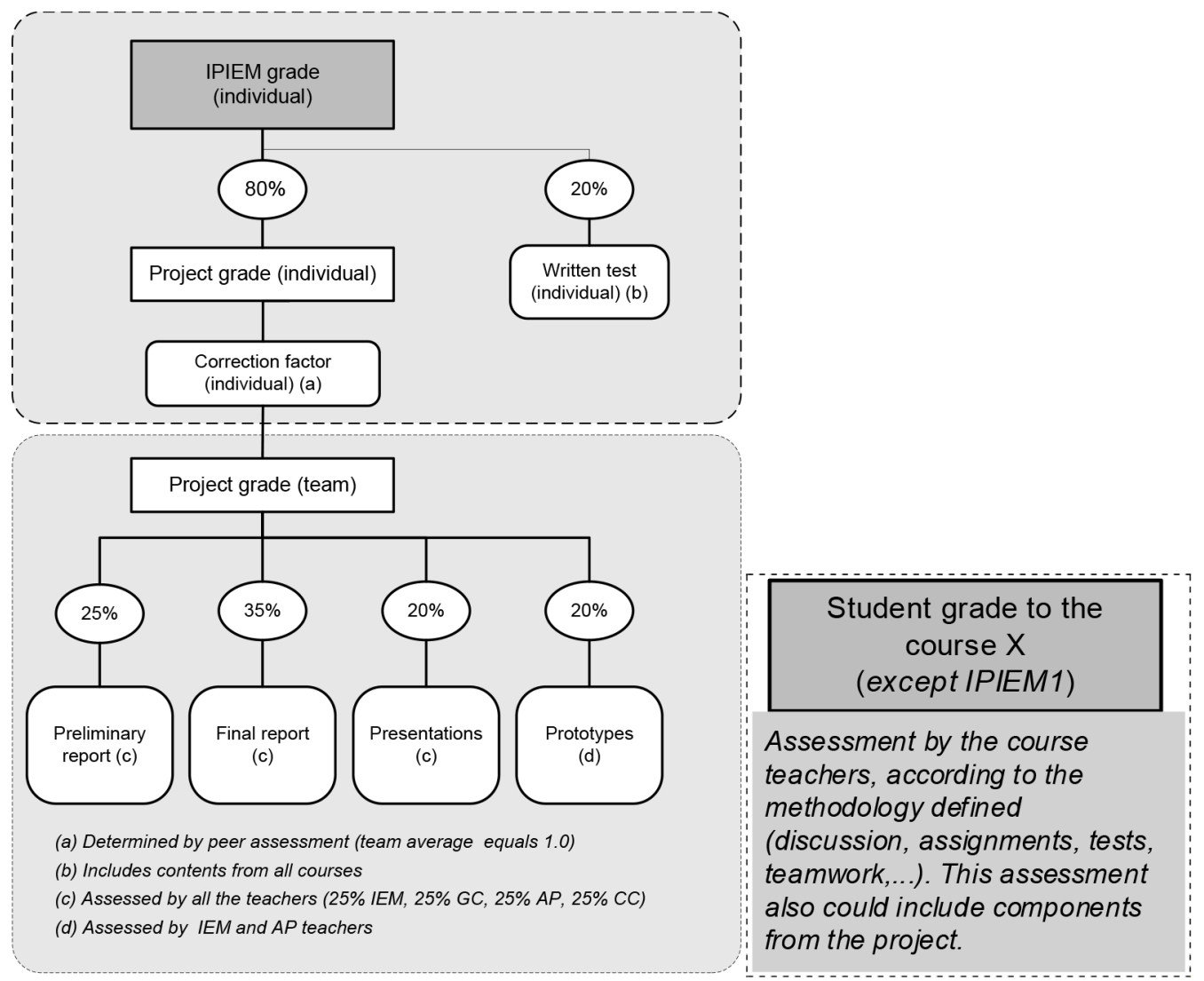

Figure 5. Assessment model of 2012/2013 edition of IPIEM1

Two main aspects are important to clarify about the project assessment: 1) the weight of the project on the course assessment and 2) the individual written test. The first one is related to the weight teachers want to give to the course contents applied by the students in the project. The IPIEM1 is a course with a specific grade depending on the components in Figure 5, but, even so, some teachers (e.g. General Chemistry), are afraid that the students do not make a bigger effort in the project and relate this project grade with the course grade. This is defined in the project assessment model represented in the Figure 5. Others, like TIEM teachers, decided that the grade of the project is the one that the student teams obtain from all components of the Figure 5 (presentations, reports, prototypes, correction factor and written test).

The other aspect is the individual written test, which is elaborated in order to: 1) assess the individual competences acquired by the students in the project and 2) prevent the students, especially the "free-riding" students, of being evaluated only by peer assessment. Each teacher prepares a test for each team, based on their own project.

Previous research showed that the assessment model, and, in particular, this test, has been considered by the students as not reflecting their knowledge and effort that they applied in the project (Fernandes et al., 2009; Alves et al., 2012a, Fernandes, Flores \& Lima, 2012; Fernandes, Mesquita, Flores \& Lima, 2014). 


\section{Research Methodology}

The methodology used in this research followed a qualitative approach aimed at analyzing the teachers' perceptions in regard to the implementation of PBL. Teachers of two particular editions: 2012/2013 and 2013/2014 were involved in the research, some with a long experience in PBL and acting in different roles and others with little experience. In other words, this research aims to identify the main difficulties which PBL raises and define effective strategies to support teachers in managing these difficulties. Some of these difficulties have already been identified in previous research (Lima et al., 2009, Mesquita et al., 2009; Fernandes et al., 2012; Fernandes et al., 2014; Alves et al., 2015a).

However, a new perspective based on course teachers' views and experiences will deepen the understanding of these problems and provide inputs for the development of strategies that may improve the effectiveness of PBL and introduce changes for its successful implementation. These strategies are intended to be transferable to other contexts, as most of the problems and constraints are common to other active learning approaches. As so, this study aims to give answer to the following research questions:

1. How do teachers evaluate the implementation of PBL in the IEM program?

2. What are the main difficulties felt by course teachers?

3. What effective strategies can help teachers to manage PBL difficulties?

For data collection, a survey was developed to collect feedback from the course teachers. The survey included 12 open-ended questions based on six main themes:

4. Overall evaluation of PBL semester

5. Course project support hours

6. Integration of the courses in the project

7. Weight of the project on the course assessment

8. Project milestones and process evaluation

9. Written test about the project content

10. Suggestions for improvement

In total, eight teachers participated in this survey. The survey was applied at the end of the PBL semester (February 2014) of 2013/2014 edition. The data analysis was based on a summary of the main ideas provided by teachers of each of the five courses involved in PBL: TIEM, LAlg, CC, GC and AP. The data are organized and presented according to the six themes included in the survey. Discussion and 
reflection on the findings are presented in the fifth section of the paper, as well as the recommended strategies for overcoming PBL difficulties.

\section{Teachers' Perspective of PBL_IEM11 Difficulties}

After collecting all surveys of the eight teachers involved in the two editions (2012 to 2014), the results that follow were synthesized to respond to the questions raised to each course teacher.

\subsection{Overall Evaluation}

The first theme approached in the survey was the teachers' perspective related with their global participation in the PBL_IEM11 project. The question was formulated as "In general terms the most positive/negative aspects of this experience were...". Each teacher response was collected and registered in a table, being organized by courses. The Table 3 resumes the positive aspects referred by the different teachers of different courses as being their overall evaluation in the IEM11_PBL.

\begin{tabular}{|c|c|}
\hline Course & Positive aspects \\
\hline TIEM & $\begin{array}{l}\text { + Involvement with teachers \& students and satisfaction of reaching the end and watch the "growth" of the } \\
\text { students \& maturity level of "well-being" } \\
+ \text { Presentations reveal development of oral expression competence in the context of exposure to large } \\
\text { audiences } \\
+ \text { Some dynamism in the search for information and contacts with companies/organizations towards problem } \\
\text { solving }\end{array}$ \\
\hline LAlg. & $\begin{array}{l}\text { + Interdisciplinary, application of methods and "abstract" concepts of Linear Algebra to real problems and } \\
\text { the experience of the usefulness of mathematics, in particular, of LAlg., to solve several design problems. }\end{array}$ \\
\hline $\mathrm{CC}$ & $\begin{array}{l}+ \text { Ability of students to work in teams, developing transferable competences important for their } \\
\text { professional development. } \\
+ \text { Students have to think of a project that includes several courses, forces them to think in a context of their } \\
\text { learning. }\end{array}$ \\
\hline GC & $\begin{array}{l}+ \text { Allow motivate students to study chemistry } \\
+ \text { Closest contact with students allows more quickly identify individual difficulties and act in class in order to } \\
\text { overcome these difficulties. }\end{array}$ \\
\hline $\mathrm{AP}$ & $\begin{array}{l}+ \text { Process of integration of courses and the consequences for the commitment, cohesion and understanding } \\
\text { of the holistic perspective of courses } \\
+ \text { Opportunity for students to apply what they are learning while they are learning } \\
+ \text { Development of students' competencies in communication, team-work and planning }\end{array}$ \\
\hline
\end{tabular}

Table 3. Overall evaluation - positive aspects

The negative aspects were also identified by teachers and are summarized in Table 4 . 


\begin{tabular}{|c|c|}
\hline Course & Negative aspects \\
\hline TIEM & $\begin{array}{l}\text { - Restricted spaces for teams of students (four teams in one room) } \\
\text { - Lack/difficulty integrating the project by some courses } \\
\text { - Some problems in the assessment model } \\
\text { - Students do the activities by need, not by the pleasure of learning }\end{array}$ \\
\hline LAlg. & $\begin{array}{l}\text { - Students have left the task to the end, to the last minute } \\
\text { - They have not met some deadlines set } \\
\text { - They did not attend all support classes of the course }\end{array}$ \\
\hline $\mathrm{CC}$ & - This last year students had little concern for the project \\
\hline GC & $\begin{array}{l}\text { - Considering the time invested in the preparation of the project and support given to students along the } \\
\text { semester, the feedback of the students was not so positive as expected } \\
\text { - Need for adjustment of the course syllabus every year to address the problems of the project } \\
\text { - Students were not aware of the impact that the classification of the project could have on the final individual } \\
\text { classification of each one in the course } \\
\text { - Underactive attitude displayed by the students of this course in the identification of the most relevant } \\
\text { aspects of the project in which it would be appropriate to apply the contents of the course. } \\
\text { - Compartmentalized knowledge by the students and difficulty in integrating the course's objectives into the } \\
\text { project considering the level of applications to new situations. }\end{array}$ \\
\hline AP & - Difficulty/non-achievement of certain objectives. The unmonitored effort. \\
\hline
\end{tabular}

Table 4. Overall evaluation - negative aspects

\subsection{Course Project Support Hours}

Each course has $1.5 \mathrm{~h} /$ week to support the six teams, i.e., 15 minutes per team. When teachers were questioned about this, by asking: 'Do you consider that the support hours to assist students' teams in the project are sufficient?" their response was unanimous: this time is sufficient, but the students' team did not take advantage of these hours (Figure 6).

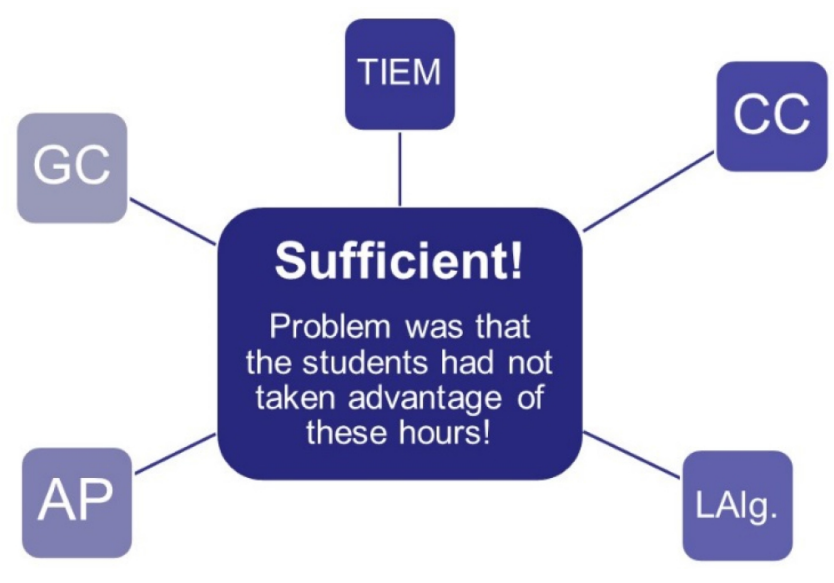

Figure 6. Teachers of different courses answers to the support hours given to the students 


\subsection{Integration of the Courses in the Project}

The third group of questions was about the integration of the course contents in the project. To the question: "I think the theme of the project was adequate/inadequate for the integration of my course in design, because...", some teachers were unanimous but AP teacher did not agree. His response is registered in the Figure 7 as well as the responses from the other teachers.

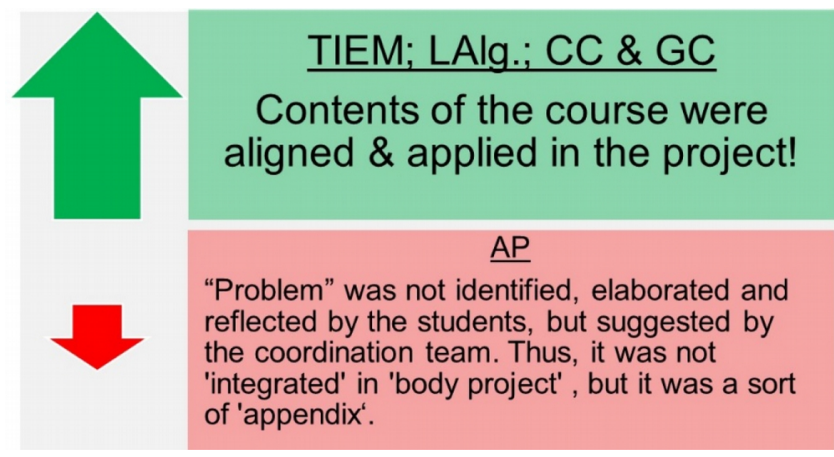

Figure 7. Teacher's opinion about the integration of the course in the project

Additionally, the teachers were asked about how they could improve their course contribution in the project attended to the potentials and limitations of the course in the project. Their responses by course are registered in Table 5 .

\begin{tabular}{|l|l|}
\hline Course & $\begin{array}{l}\text { The contribution of my course in the project could be improved (refer to the potentials and limitations of the } \\
\text { course in the project)... }\end{array}$ \\
\hline TIEM & $\begin{array}{l}\text { - Increment level of demand and rigor regarding some aspects of the design of the production system (e.g. } \\
\text { layout, performance indicators, etc.) }\end{array}$ \\
\hline LAlg. & $\begin{array}{l}\text { - More knowledge and information about the project itself and on the applications of other courses } \\
\text { in the project, since other possible contributions of LAlg. can be found in order to solve problems also in } \\
\text { the context of other courses. For LAlg., which is a subject considered "abstract", it is interesting to have } \\
\text { applications to concrete, real problems from other areas. }\end{array}$ \\
\hline CC & $\begin{array}{l}\text { - The topics involved in the project were calculation of areas and volumes of solids of revolution. Students } \\
\text { must create solids fostering their creativity. However, this aspect was not valued by them. }\end{array}$ \\
\hline GC & $\begin{array}{l}\text { If students already possess some basic knowledge, more advanced content could be included in the } \\
\text { project. }\end{array}$ \\
\hline AP & $\begin{array}{l}\text { I believe that the integration of AP could be better achieved if 'linked' to matters of Calculus or Algebra } \\
\text { or even the overall project management of the group. }\end{array}$ \\
\hline
\end{tabular}

Table 5. Answers to the course contribution improvement in the project 


\subsection{Weight of the Project on the Course Assessment}

The fourth theme was about the weight of the project on the course assessment. That was questioned in this way: "I believe that the weight of the project in the course assessment is/is not balanced, because...". The results are presented in Figure 8.

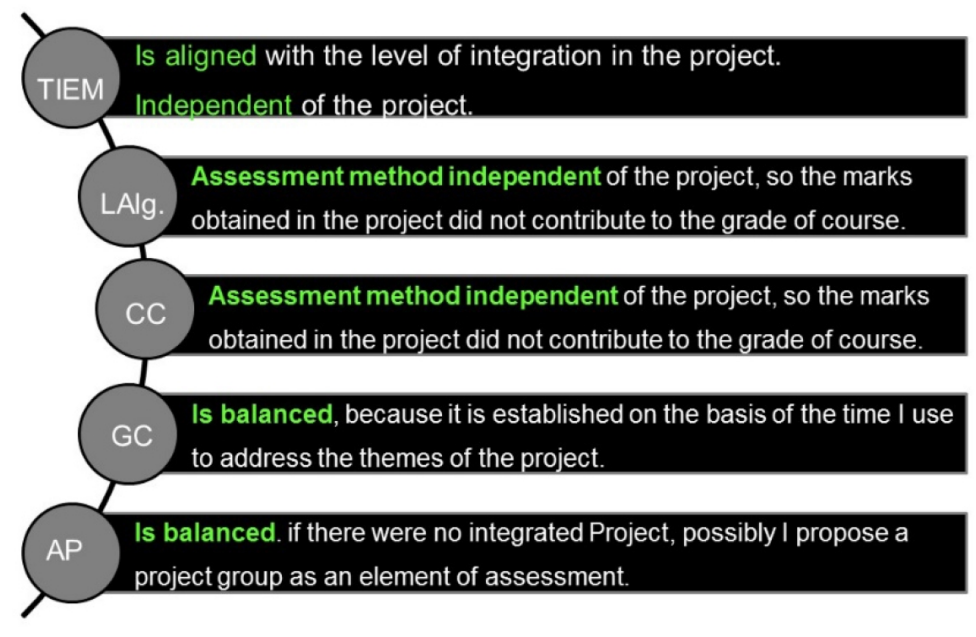

Figure 8. Responses to the weight of the project on the course assessment

\subsection{Project Milestones and Process Evaluation}

The theme five grouped questions about: 1) the milestones and if they should/ should not be assessed; 2) the assessment by other student teams of the preliminary reports and 3) the peer assessment usefulness.

Almost all teachers were unanimous about the assessment of the milestones, except one. This teacher said "some should, others no", but he did not specify much more. The others invoked common and different reasons for this importance as shown in the Figure 9.

\begin{tabular}{|c|c|c|c|c|}
\hline \multicolumn{5}{|c|}{ Should be assessed } \\
\hline TIEM & LAlg. & $\mathrm{CC}$ & GC & $\mathrm{AP}$ \\
\hline $\begin{array}{l}\text { Excellent } \\
\text { way to } \\
\text { monitor the } \\
\text { progress of } \\
\text { the project }\end{array}$ & $\begin{array}{l}\text { Aid to } \\
\text { guide the } \\
\text { students in } \\
\text { order to } \\
\text { understand } \\
\text { how their } \\
\text { work is } \\
\text { going on } \\
\text { and what } \\
\text { they should } \\
\text { improve. }\end{array}$ & $\begin{array}{l}\text { Assess the } \\
\text { progression } \\
\text { and } \\
\text { evolution of } \\
\text { the work. } \\
\text { Continuous } \\
\text { assessment } \\
\text { better } \\
\text { reflects the } \\
\text { work } \\
\text { performed }\end{array}$ & $\begin{array}{l}\text { Allows } \\
\text { students to } \\
\text { receive } \\
\text { quantitative } \\
\text { feedback of } \\
\text { their } \\
\text { performance } \\
\text { and thus } \\
\text { may improve } \\
\text { their overall } \\
\text { performance }\end{array}$ & $\begin{array}{l}\text { Such } \\
\text { assessment } \\
\text { have some } \\
\text { weight in } \\
\text { the final } \\
\text { grade } \\
\text { because it } \\
\text { reflects the } \\
\text { importance } \\
\text { of the whole } \\
\text { process }\end{array}$ \\
\hline
\end{tabular}

Figure 9. Reasons for the milestones assessment 
At the same time, almost all teachers believed that the assessment of the preliminary reports by other student teams was useful for student learning because of the possibility they had to see other reports and receive feedback from the colleagues. Each course teacher recalled different positive aspects:

- TIEM: Show to the teams some clues on how to do (or not do), what is missing in their report, helping them to develop critical thought. On the other hand, they can better understand what is expected from them, from teachers (when they read and evaluate the work of colleagues put themselves in the role of a teacher).

- LAlg.: Possibility that students have to do a thorough analysis of another report, also comparing it to their own work. It also serves as a way for study and revision.

- CC: Enhance the work done. It is important the feedback given to students by their peers.

- GC: Allows students to gain insight on their performance relative to their peers.

- AP: this is a positive aspect and added: “...But has a dimension which is being wasted - a concrete improvement of communication skills (writing/speaking) of students, i.e., any report should not be accepted and therefore evaluated if they were not formally corrected".

One teacher of the TIEM teachers group did not agree with that vision. His opinion was: "not useful; the fact that they [the students] could influence each other grade, supposedly evaluating technical contents, it is unrealistic and even counterproductive. It has occurred, at least occasionally, unrealistic grades, which indicates at least some negligence in assigning the rating.". However, this teacher focused his answer only in the gradin, not in the usefulness of the feedback.

In this group of questions, it was also asked to the teachers about their opinion of peer assessment among the team members and the responses were:

- TIEM: Allow the group to reflect about their actual involvement of each member on the group project. Instead of being seen as a mechanism for "penalty/ recovery", it serves to responsibility of all members and importance of engagement at work.

- LAlg.: It enables a better acquaintance of the students with their own skills and expertise and with those of other peers in the group in order to organize better the tasks of the group and to work better as a team.

- CC: Openly reflect on teamwork. It is important to give constructive criticism about teamwork. It also enables the development of their emotional skills, important in their future job context.

- GC: Make clear and unequivocal opinion that each one has about the performance of others as active individuals who contribute/or should contribute equally to the final result. 
- AP: Improve the performance of students and for them to become aware of the issue of evaluating.

\subsection{Written Test About the Project Content}

When asked to the teachers what they think is the goal of the student individual written test about the project content, all answered that this test assesses fairly the individual work of each member of a group for the project thus contributing to a greater distinction of grades. They also answered about what were their main concerns when elaborating the questions on the subject of their UC that are represented in Figure 10.

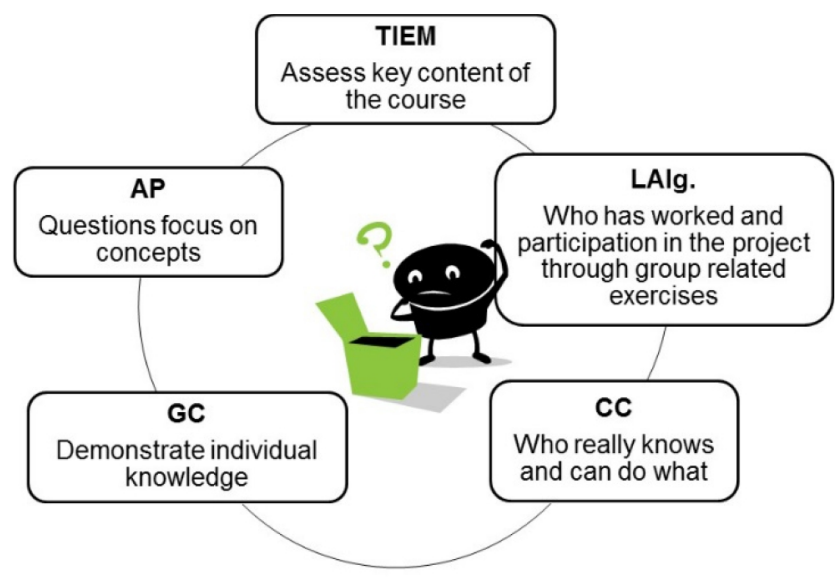

Figure 10. Teachers' main concerns when elaborating questions for written test 


\subsection{Improvements Suggestions}

Finally, the seventh question was about improvement suggestions. Table 6 presents the results of improvements suggestions that each course teacher considered for PBL experience improvement.

\begin{tabular}{|c|c|}
\hline Course & To improve the experience of PBL, I would like to have... \\
\hline TIEM & $\begin{array}{l}\text { - Bigger spaces for the teams } \\
\text { - Better integration of the contents of some courses in the project } \\
\text { - Reanalysis of the assessment model }\end{array}$ \\
\hline LAlg. & $\begin{array}{l}\text { - More information about the project and the theme, discussing each course application and period time to } \\
\text { implement }\end{array}$ \\
\hline $\mathrm{CC}$ & $\begin{array}{l}\text { - Lower number of students in each team (nine is a big number) } \\
\text { - If each course presents the objectives for each own course in the initial meeting maybe some cross } \\
\text { cutting could be meet and explored in different way }\end{array}$ \\
\hline GC & - No suggestion \\
\hline $\mathbf{A P}$ & $\begin{array}{l}\text { - Biggest concern/involvement of teachers in the identification/selection of topics where students could } \\
\text { work more and better interdisciplinary } \\
\text { - The time monitoring of the actual work of students } \\
\text { - Reports and presentations formally correct } \\
\text { - Overcome the students compartmentalized knowledge }\end{array}$ \\
\hline
\end{tabular}

Table 6. Improvement suggestions given by teachers

\section{Discussion of Results and Recommended Strategies}

The PBL methodology is an active methodology that involves students in their own learning process. There are a lot of papers in the literature proving this, e.g. some papers of the same authors of this paper (Alves et al., 2012a; Fernandes et al., 2012; Alves, Mesquita, Moreira \& Fernandes, 2012b; Fernandes et al., 2014; Alves et al., 2015b). Less common are papers about what PBL implies for teachers' practices and this has been also concern of authors of this paper (Lima et al., 2009; Mesquita et al., 2009; Alves et al., 2015a) and, particularly, how they overcome difficulties in this implementation.

So, this paper is about the teachers' perceptions and feelings when involved in the PBL process and the way they overcome some of the difficulties imposed in the first year of Industrial Engineering and Management program with a curriculum based on six different courses taught by teachers of different schools and departments. These teachers have different backgrounds and research in different areas but when the subject is the students' learning process, all want the same: that students learn in a meaningful way.

From the results above, and in general terms, teachers are joined by the same motive and seemed motivated and pleased with the results achieved in the IEM11_PBL. The teachers involved in the PBL_IEM11 program worked in team and there was a good communication and collaboration between 
them. For the student teams, to see that teachers are united and work as a team, acted as an inspiration source and an example for them. So, a good communication and collaboration between the teachers involved in the PBL process is a key strategy to achieve success in the process.

During a decade, a lot of changes and enhancements had taken place in IEM11_PBL due to a continuous improvement cycle that involved students, teachers, tutors and educational researchers. All of them are stakeholders interested that this process works well, so they work together towards this aim. Therefore, having discussions and feedback from students, teachers, tutors and educational researchers about the PBL process is another key strategy to success.

In spite of the teachers' positive evaluation of the PBL implementation, they admit having felt some difficulties. Four main different areas have been identified: integration of the contents of some courses in the project, students' assessment, the growing number of students in each team and the need of physical spaces for them and the compartmentalized knowledge.

Sometimes, it is difficult for some teachers to align the contents of the course with project theme because they are too much worried about this content and they still think that if they don't teach, student don't learn. This happen because they are not prepared to abdicate of their traditional role as a teacher (in the center of the learning process) and don't realize that they do not need to know everything or answer to all doubts of students. Students must have their share of responsibility in being proactive learners and pull the learning from the teacher. Of course, teachers in PBL need to be prepared to adjust the contents of their course according to the project theme. General Chemistry teacher in PBL_IEM11 normally do this, so this is a key strategy to success.

Additionally, when a course teacher noticed that the students are not learning the contents as they should, teachers must rethink what they can do to promote the learning process. For example, in a study of Colombo, Alves, van Hattum-Janssen and Moreira (2014) the development of adequate levels of sustainability awareness was not totally achieved and the authors realized that more should be done to enable students to transform knowledge into competences of devising and applying sustainability concepts. This was the main reason to rethink sustainability education on IPIEM1 and the proposal of additional actions such as a specific workshop focused on sustainability issues (Colombo, Moreira \& Alves, 2015).

Students' assessment is always a motive of discussion and discomfort for them as they feel the effort they put in the project is not rewarded by the grades they obtain. One of the important curricular changes operated in the IEM11_PBL came from students' proposals: to include IPIEM1 as a course (Alves et al., 2015b) and that this should be treated as a course like the others with an own grade, independent from the courses grades as was before. But this just adds more anxiety in the students, as they see regular 
grades, not as high as they wanted. Additionally, one teacher still felt the need to integrate components from the project in the course assessment (to push students to be concerned about the project). Fortunately, this teacher realize the injustice was creating and finish with this. The individual written project test was also removed in the last year edition (2014-2015) and substituted by a different mechanism (Moreira, Fernandes, Malheiro, Ferreira, Costa \& Rodrigues, 2015). This mechanism is still in testing.

Previous research (e.g., Powell \& Weenk, 2003) suggests that the student teams must have their own space to work, as illustrated in Figure 11, to share calendars of the team, to visualize important information, to meet the tutor or the teachers, to build and discuss the prototypes among others. Thus, one more key strategy to success is that each project team has its own work space and is responsible for its use.

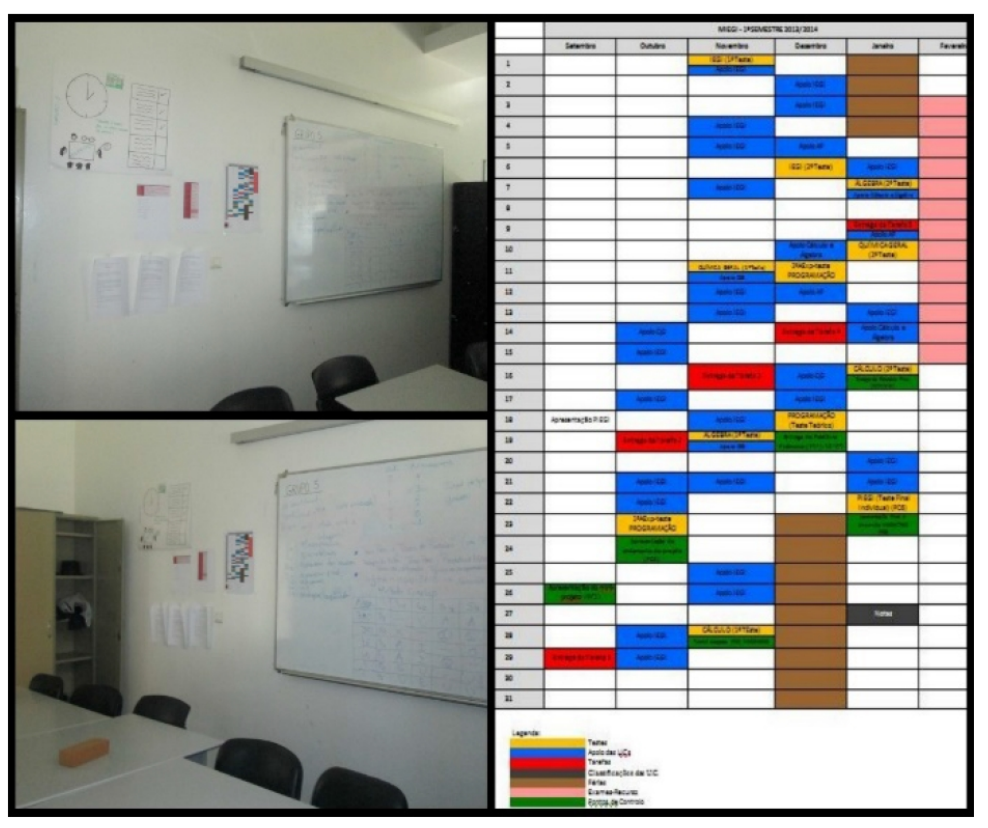

Figure 11. Project room with a student team space

As a coordinator of three editions of PBL, the first author of this paper had the opportunity to serve, many times, as intermediary of the students and teachers and, sometimes, what the first wants is not what the second thinks. For example, normally, teachers think students will be engaged with the project theme and this does not happen. Also, students never like to be assessed or to assess and teachers need to discuss with them why this is important. Of course, some teachers also preferred not to do so but a grade must be filled. Students are warned to do a calendar and not left tasks to do at the last minute, but they are always doing this. 
Resulting from the growing number of members in a team (nine members) and the high number of tasks to do, students tend to divide tasks between them which is natural of teamwork but the way they contribute and share the small group activities could an issue (Kamp, Dolmans, van Berkel \& Schmidt, 2012). Many times, students don't share the knowledge between them, mainly due to doing tasks at last hour. To avoid this, they had been encouraged to use tools such as a blog to write all activity they are doing. This could be a key strategy, not only for them to share work between them but also for teachers monitoring their work (Vicente, Mattarredona \& Alves, 2014).

As conclusion, there are many improvements still to do as seen in Table 6 of the improvement suggestions, but some of them cannot be implemented, such as reducing the number of students in each team, since this depends on infra-structures that are limited (few project rooms). Other improvements will be made as good communication, collaboration and good will from the teachers continue because PBL is a worthwhile active methodology to engage students in their own learning but demands a huge effort from the teachers, who sometimes are not prepared to compromise. Moreover, when the faculty does not recognize the teaching activity as the main value of higher education institutions, the effort is not compensated and this could be a drawback, since the effort that the teachers have to develop throughout all the activities, performed along the semester with students, may be not very motivating.

\section{Final Remarks}

This paper presented the results of teachers' perceptions and feelings about difficulties and needs when involved in IEM11_PBL. These indicated a relevant level of critical reflection contributing to the PBL evaluation process. Teachers' reflection shared a positive opinion about the use of PBL as a learning methodology. The main difficulties of this PBL experience were identified as being mainly four: 1) integration of courses in the project; 2) student assessment; 3) growing number of students in each team and the need of physical spaces for them; and 4) compartmentalized knowledge.

Fundamental lines of improvement of the learning process are related mainly to the student's assessment model (peer included) and integration of the courses (collaborative work). Some key strategies such as good communication and collaboration between teachers, continuous feedback from all stakeholders, course contents adjustment, reflecting about teaching and assessing practices, work team spaces and use of teamwork sharing tools. Improvements suggestions are always important for the course design and planning.

PBL is aligned with the students', professionals' and society's new demands, but implementation of PBL is not an easy process because there are: 1) barriers from infra-structures and spaces; 2) difficulties from other 
teachers and students; 3) teamwork (coordination) conflicts; 4) project management complexity. Even so, PBL leads to higher professional satisfaction and the students build up technical competencies and nontechnical skills, more directed to work market requirements and this fact rises students' motivation. Also, PBL is an opportunity for teachers from Engineering, Science and Education to work together.

\section{References}

Alves, A.C., Mesquita, D., Moreira, F., \& Fernandes, S. (2012b). Teamwork in Project-Based Learning: engineering students' perceptions of strengths and weaknesses. International Symposium on Project Approaches. S. Paulo, July 26-27.

Alves, A.C., Moreira, F., Lima, R.M., Sousa, R.M., Carvalho, J., Mesquita, D. et al. (2012a). Project Based Learning in First Year, First Semester of Industrial Engineering and Management: Some Results. Proceedings of the ASME 2012 International Mechanical Engineering Congress \& Exposition (IMECE2012). Houston, TX, November 9-15. http://dx.doi.org/10.1115/imece2012-89046

Alves, A.C., Moreira, F., Lima, R.M., Sousa, R.M., Carvalho, D., Mesquita, D. et al. (2015b). Aprendizagem baseada em projetos interdisciplinares: análise da implementação em duas estruturas curriculares distintas. In Linguagens em uso nas Engenharias. Edifurb - Editora da FURB.

Alves, A.C., Moreira, F., Sousa, R.M., \& Lima, R.M. (2009). Teachers' workload in a project-led engineering education approach. Proceedings of the International Symposium on Innovation and Assessment of Engineering Curricula. U. Dominguez (Ed.), Valladollid, Spain, 15-17 May. 41-52.

Alves, A.C., Sousa, R.M., Fernandes, S., Cardoso, E., Carvalho, M.A., Figueiredo, J. et al. (2015a). Teacher's experiences in PBL: implications for practice. European Journal of Engineering Education., 41(2), 123-141. http://dx.doi.org/10.1080/03043797.2015.1023782

Bédard, D., Lison, C., Dalle, D., Côté, D., \& Boutin, N. (2012). Problem-based and Project-based Learning in Engineering and Medicine: Determinants of Students' Engagement and Persistance. Interdisciplinary Journal of Problem-based Learning, 6(2), 7-30.

Colombo, C.R., Alves, A.C., van Hattum-Janssen, N., \& Moreira, F. (2014). Active learning based sustainability education: a case study. Proceedings of the Sixth International Symposium on Project Approaches (PAEE2014). Medellin, Colombia, July 27-28. ID55.1-55.9. http://hdl.handle.net/1822/30173 
Colombo, C.R., Moreira, F., \& Alves, A.C. (2015). Sustainability Education in PBL Education: the case study of IEM-UMINHO. In Proceedings of the Seventh International Symposium on Project Approaches in Engineering Education (PAEE'2015), integrated in the International Joint Conference on the Learner in Engineering Education (IJCLEE'2015). Mondragon University, Donostia, San Sebastian, Spain, July 6-9. Aalborg University Press, Denmark. 214-221. ISBN: 978-87-7112-305-0; ISSN: 2183-1378. http://hdl.handle.net/1822/39124

Dewey, J. (1916). Democracy and Education. An introduction to the philosophy of education. New York: Free Press.

Edström, K., \& Kolmos, A. (2014). PBL and CDIO: complementary models for engineering education development. European Journal of Engineering Education, 39(5), 539-555.

http://dx.doi.org/10.1080/03043797.2014.895703

European Commission (2013). Improving the quality of teaching and learning in the Europe's Higher Education Institutions. Report for the European Commission by the High Level Group on the Modernization of Higher Education.

European Ministers of Education (1999). The Bologna Declaration of 19 June 1999. The European Higher Education Area.

Fernandes, S., Flores, M.A., \& Lima, R.M. (2012). Student's Views of Assessment in Project-led Engineering Education: Findings from a Case Study in Portugal. Assessment \& Evaluation in Higher Education, 37(2), 163-178. http://dx.doi.org/10.1080/02602938.2010.515015

Fernandes, S., Lima, R.M., \& Flores, M.A. (2009). Project-Led Education from faculty staff's perspective: a case study of Engineering Education in Portugal. Paper presented at the 2nd International Research Symposium on PBL (IRSPBL'2009). Melbourne, Australia.

Fernandes, S., Mesquita, D., Flores, M.A., \& Lima, R.L. (2014). Engaging students in learning: findings from a study of project-led education. European Journal of Engineering Education, 39(1), 55-67. http://dx.doi.org/10.1080/03043797.2013.833170

Graaff, E., \& Kolmos, A. (2003). Characteristics of Problem-Based Learning. International Journal of Engineering Education, 19(5), 657-662.

Graaff, E., \& Kolmos, A. (Eds.) (2007). Management of Change: Implementation of Problem-Based and Project-Based Learning in Engineering. Roterdam: Sense Publishers.

Helle, L., Tynjälä, P., \& Olkinuora, E. (2006). Project-based learning in post-secondary education - theory, practice and rubber sling shots. Higher Education, 51(2), 287-314. http://dx.doi.org/10.1007/s10734-004-6386-5 
Jollands, M., Jolly, L., \& Molyneaux, T. (2012). Project-based learning as a contributing factor to graduates' work readiness. European Journal of Engineering Education, 37(2), 143-154.

http://dx.doi.org/10.1080/03043797.2012.665848

Kamp, R.J.A., Dolmans, D.H.J.M., van Berkel, H.J.M., \& Schmidt, H.G. (2012). The relationship between students' small group activities, time spent on self-study, and achievement. Higher Education, 64, 385-397. http://dx.doi.org/10.1007/s10734-011-9500-5

Kilpatrick, W.H. (1918). The project method. Teachers College Record, 19, 319-335.

Kilpatrick, W.H. (1921). Dangers and difficulties of the project method and how to overcome them: Introductory statement: Definition of terms. Teachers College Record, 22(4), 283-287.

King, C.J. (2012). Restructuring Engineering Education: Why, How And When? Journal of Engineering Education, 101(1), 1-5. http://dx.doi.org/10.1002/j.2168-9830.2012.tb00038.x

Lima, R.M., Carvalho, D., Flores, M.A., \& van Hattum-Janssen, N. (2007). A Case Study on Project Led Education in Engineering: Students' and Teachers' Perceptions. European Journal of Engineering Education, 32(3), 337-347.

Lima, R.M., Carvalho, D., Sousa, R.M., \& Alves, A.C. (2009). Management of Interdisciplinary Project Approaches in Engineering Education: a Case Study. In Carvalho, D., van Hattum-Janssen, N., \& Lima, R.M. (Eds.). First Ibero-American Symposium on Project Approaches in Engineering Education - PAEE2009. Guimarães, Portugal. 149-156. http://dx.doi.org/10.1080/03043790701278599

Mesquita, D., Alves, A., Fernandes, S., Moreira, F., \& Lima, R.M., (2009). A First Year and First Semester Project-Led Engineering Education Approach. In Carvalho, D., van Hattum-Janssen, N., \& Lima, R.M. (Eds.). First Ibero-American Symposium on Project Approaches in Engineering Education - PAEE2009. Guimarães, Portugal. 181-189.

Moreira, F., Fernandes, S., Malheiro, M., Ferreira, C., Costa, N., \& Rodrigues, C. (2015). Assessing student individual performance within PBL teams: findings from the implementation of a new mechanism. In "Global Research Community: Collaboration and Developments". In Graaff, E., Guerra, A., Kolmos, A., \& Arexolaleiba, N.A. (Eds.). Proceedings of the 5th International Research Symposium on Problem Based Learning. Aalborg University Press, Denmark. 35-47. ISBN: 978-87-7112-304-3.

Moreira, F., Mesquita, D., \& van Hattum-Janssen, N. (2011). The importance of the Project Theme in Project-Based Learning: a Study of Student and Teachers Perceptions. In Carvalho, D., van Hattum-Janssen, N., \& Lima, R.M. (Eds.). Proceedings of the 3rd Ibero-American Symposium on Project Approaches in Engineering Education (PAEE’2011). Lisboa-Portugal. 65-71 (CD-ROM). ISBN: 978-989-8525-05-5. 
Moreira, F., Sousa, R.M., Leão, C.P., Alves, A.C., \& Lima, R.M. (2009). Measurement Rounding Errors in an Assessment Model of Project Led Engineering Education. International Journal of Online Engineering (iJOE), 5(2). 39-44. ISSN: 1861-2121.

Powell, P.C., \& Weenk, W. (2003). Project-Led Engineering Education. Utrecht: Lemma.

Prince, M. (2004). Does active learning work? A review of the research. Journal of Engineering Education, 93(3), 223-231. http://dx.doi.org/10.1002/j.2168-9830.2004.tb00809.x

Vicente, S., Mattarredona, E., \& Alves, A.C. (2014). The Importance of Blog as a Communication Tool to Support the Development of Project-Based Learning. Proceedings of the Sixth International Symposium on Project Approaches (PAEE2014). Medellin, Colombia. July 27-28. ID39.1-39.9. http://hdl.handle.net/1822/30133

Zhang, Q., Zimmerman, J., Mihelcic, J., \& Vanasupa, L. (2008). Civil and Environmental Engineering Education (CEEE) Transformational change: tools and strategies for Sustainability integration and assessment in Engineering Education. Proceedings of the 2008 American Society for Engineering Education Annual Conference \& Exposition.

Journal of Industrial Engineering and Management, 2016 (www.jiem.org)

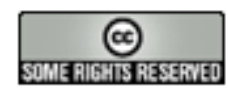

Article's contents are provided on an Attribution-Non Commercial 3.0 Creative commons license. Readers are allowed to copy, distribute and communicate article's contents, provided the author's and Journal of Industrial Engineering and Management's names are included. It must not be used for commercial purposes. To see the complete license contents, please visit http://creativecommons.org/licenses/by-nc/3.0/. 